\title{
Aboveground and Belowground Colonization of Vegetation on a 17-Year-Old Cover with Capillary Barrier Effect Built on a Boreal Mine Tailings Storage Facility
}

\author{
Alex Proteau ${ }^{1}$, Marie Guittonny ${ }^{2, *}$, Bruno Bussière ${ }^{2}$ and Abdelkabir Maqsoud ${ }^{1}$ \\ 1 RIME-Research Institute on Mines and the Environment, Université du Québec en Abitibi-Témiscamingue, \\ 675, 1re Avenue, Val-d'Or, QC J9P 1Y3, Canada; Alex.Proteau@uqat.ca (A.P.); \\ abdelkabir.maqsoud@uqat.ca (A.M.) \\ 2 RIME-Research Institute on Mines and the Environment, Université du Québec en Abitibi-Témiscamingue, \\ 445 boul. de l’Université, Rouyn-Noranda, QC J9X 5E4, Canada; Bruno.Bussiere@uqat.ca \\ * Correspondence: Marie.Guittonny@uqat.ca
}

Received: 26 June 2020; Accepted: 6 August 2020; Published: 8 August 2020

check for updates

\begin{abstract}
Acid mine drainage is an important environmental risk linked to the surface storage of reactive mine tailings. To manage this problem, a cover with a capillary barrier effect (CCBE) can be used. This oxygen barrier cover relies on maintaining a fine-grained material layer (moisture-retaining layer, MRL) with a high degree of saturation. CCBEs can be colonized by surrounding plants. Plant roots pump water and could impact CCBE's performance. This performance is predicted with unsaturated water flow numerical models in which vegetation parameters can be included. Vegetation parameters may be specific in a CCBE environment. Therefore, analyzing and quantifying the vegetation that colonizes this type of cover is necessary. Plant colonization was investigated through cover and density surveys on 12 transects on a 17-year-old CCBE in the mixed forest of Quebec, Canada. Then, aboveground vegetation and root colonization intensity at three depths in the MRL were characterized on 25 plots of five dominant vegetation types (Salix, Populus, Alnus, Picea sp., and herbaceous species). The mean root length density under plots dominated by Salix sp. was higher than in the other plots. Root colonization of the MRL was concentrated in the first $10 \mathrm{~cm}$ and occurred under all woody and herbaceous species as well. This work quantitatively describes, for the first time, the vegetation colonizing a CCBE both at the above- and belowground levels. These data will be useful to better predict the long-term performance of this engineered reclamation cover.
\end{abstract}

Keywords: biological monitoring; cover with capillary barrier effect; reclamation; mine tailings; acid mine drainage; oxygen barrier cover in forest environment

\section{Introduction}

Several reclamation methods have been developed to control the production of acid mine drainage (AMD), one of the main environmental problems associated with the storage of mine wastes. In humid climates such as northern Quebec, one method is the use of an engineered cover, like a cover with a capillary barrier effect (CCBE) [1-13]. CCBEs aim at limiting oxygen ingress to reactive tailings because oxygen is one of the necessary ingredients in the formation of AMD [14]. In brief, CCBEs are covers with at least three layers: the top protection layer (PL), the middle moisture-retaining layer (MRL), and the bottom capillary break layer (CBL). The PL, made of coarse-grained material, reduces evaporation and limits vegetation influence on the MRL. The latter, made from fine-grained material, is the layer on which the CCBE's performance is based and keeps oxygen away from the tailings by 
maintaining a high degree of saturation $\left(S_{r}=\right.$ volume of water/volume of voids). The third layer, the $\mathrm{CBL}$, is also made of coarse-grained material and helps to create capillary barrier effects necessary to maintain a high degree of saturation in the MRL. More information on CCBE configuration and functioning can be found in $[5,10]$.

The main concern with vegetation colonizing a CCBE is the presence of roots in the MRL which has been shown to happens [15]. The PL is meant to protect the MRL from bio-intrusion, including roots. With the PL in place, woody species would be the most likely to negatively impact the CCBE due to their generally deeper root system compared to herbaceous species [16]. Tree roots could negatively impact the MRL by pumping soil water [17], which would reduce its $\mathrm{S}_{\mathrm{r}}$ and allow the oxygen to migrate through the CCBE and reach the reactive tailings. They could also create preferential pathways for oxygen and water migration through root biopores [18]. Biopore formation can affect the hydrogeological properties of the MRL materials, including the water retention curve [19] and the saturated hydraulic conductivity [20]. These modifications, in turn, can impact the CCBE performance. The intensity of root colonization is usually expressed through parameters such as root length density (RLD) [21,22], root volume density (RVD) [23], or root mass density (RMD) [24]. Proteau et al. [25] have worked on establishing links between root parameters and a CCBE's performance and showed that a higher RLD could increase the reactivity coefficient $\left(\mathrm{K}_{\mathrm{r}}\right)$ of the CCBE because of root's oxygen consumption while decreasing the degree of saturation $\left(\mathrm{S}_{\mathrm{r}}\right)$ of the MRL. However, studies on root colonization of cover materials remain sparse $[15,26-30]$, especially quantitative studies measuring root traits. Reference values of vegetation parameters come primarily from agricultural or forestry contexts [31], although plant root development and associated water pumping may be specific in the context of multilayered cover systems like CCBEs (e.g., due to textural discontinuity) [32].

Different plant species have different rooting types and traits that could have different impacts [33,34]. For example, herbaceous plant species usually have a shallower depth of root colonization (from 20 to $30 \mathrm{~cm}$ ) compared to trees, which can reach $7 \mathrm{~m}$ deep [16], but herbaceous species also have a higher root mass density or root length density at shallow depth [35]. A higher density of roots generally implies higher water pumping [36] and could be problematic for the CCBE. In a forested biome such as the temperate and boreal forest biomes, woody species-dominated vegetation is to be expected. Literature tells us that normally, the root colonization maximum depth should be around $150 \mathrm{~cm}$ in a boreal forest as well as in a temperate forest setting [37,38], which could reach the MRL depending on the PL thickness. Some authors have observed roots of woody species reaching depths greater than $2 \mathrm{~m}$ (Populus tremuloides on Canadian sandy substrate) or $3 \mathrm{~m}$ (Pinus contorta in southern Canada) [16]. However, all agree that roots are concentrated in the top 30 to $50 \mathrm{~cm}$ of soil where approximately $80 \%$ of root biomass is found [16,37,38]. Interestingly, roots are rarely seen growing deeper than the water table location [39] due to the lack of oxygen in saturated soil, which means that, in the case of the CCBE, roots could stop at the MRL if the degree of saturation is high. That being said, Salix sp., a woody species that usually has rooting systems deep enough to reach the MRL [40] and root tolerance to anoxic conditions [41] could colonize the MRL.

Root studies are known to be time consuming [25,42-44] and imply soil excavations that could negatively affect the integrity of an engineered cover. Since some below- and aboveground parameters of vegetation can be correlated, it could be possible to predict the degree of root colonization present in the MRL and the possible threat to the CCBE's performance from measurements on aboveground vegetation. For example, shoot diameter and coarse root biomass [45], aboveground biomass and belowground biomass [46], or aboveground biomass and maximal depth of roots colonization [47] seem to be positively linearly correlated. However, these relationships can vary depending on species and growth environment [48].

In human-made environments, like the top of the PL, woody species usually colonize promptly and are part of the primary vegetation succession [49-51]. Vegetation colonization may happen even if the PL, with its low water content and nutrient concentration, is not favorable to plant growth [15]. Indeed, natural vegetation colonization has been observed on covers made of coarse-grained materials, 
which present constraints to plant establishment such as a low water retention capacity [52] and low $\mathrm{N}$ concentrations [53]. Vegetation can also be seen on engineered covers, including a geosynthetic liner aimed at stopping water infiltration $[54,55]$. The conceptual framework of the primary vegetation succession can help predict which main species will colonize a new mine substrate $[50,56]$, including the PL of a CCBE.

The main objective of this study is to characterize the vegetation colonizing a 17-year-old CCBE in a boreal mixed forest environment both at the above- and belowground levels. The focus is especially put on measuring root parameters (like RLD, RMD and RVD as well as root diameter to compare fine and coarse roots) in the MRL of the CCBE, which acts as the oxygen barrier layer, through root coring at several depths. First, the aboveground vegetation cover and density are evaluated, following the work of Smirnova et al. on the same site, to identify the dominant woody species whose roots may reach the MRL. Second, above- and belowground parameters of vegetation are measured in plots (five replicates) under four dominant woody species or herbaceous species. The data collected here will help build the tools and feed the models that will further our understanding of root impact on this reclamation method. This paper considers three hypotheses: (1) herbaceous roots will not reach the MRL; (2) woody species roots will reach the MRL at $30 \mathrm{~cm}$ depth from the soil surface but should not go through it; (3) correlation between aboveground and belowground vegetation parameters should limit the need for direct sampling to quantify root colonization intensity in the MRL.

\section{Materials and Methods}

\subsection{Experimental Site and Its CCBE}

The Lorraine mine site is located in the Témiscamingue region of Quebec, Canada $\left(47^{\circ} 21^{\prime} 39^{\prime \prime} \mathrm{N}\right.$, $78^{\circ} 56^{\prime} 35^{\prime \prime} \mathrm{W}$ ), in the township municipality of Latulipe-et-Gaboury. From 1964 to 1968, gold, silver, copper, and nickel were extracted from the mine. Then, after four years of operation, the mine was abandoned, leaving behind 15.5 ha of acid-generating tailings that represent approximately 600,000 tons of material [57,58]. In 1999, Qubec's Ministry of Energy and Natural Resources decided to reclaim the site by reshaping the tailings storage facility, installing limestone drains to passively treat acidic effluents [59,60], building a CCBE over the tailings, and implementing a monitoring program [57]. No effort of revegetation was done, and the site was allowed to naturally regenerate. The main design objective for the CCBE was to decrease oxygen fluxes reaching the tailings to below 20 to $40 \mathrm{~g} / \mathrm{m}^{2} /$ year by maintaining a minimum $\mathrm{S}_{\mathrm{r}}$ of $85 \%$ in the MRL [57].

The CCBE on which the analyses were performed is made of three layers. The bottom layer, the CBL, is approximately $30 \mathrm{~cm}$ thick and made of sand. The middle layer is the MRL, a $50 \mathrm{~cm}$ thick silt layer. The porosity (n) of the CBL is about 0.38 [57]. It has a high saturated hydraulic conductivity of approximately $10^{-3} \mathrm{~cm} / \mathrm{s}$, which is $10^{2}$ to $10^{3}$ times higher than the silt used in the middle layer. In comparison, the $\mathrm{n}$ of the MRL is on average 0.34 , with a high degree of saturation ( $\approx 0.93)$ [25]. Finally, the top layer of the Lorraine site CCBE is the protection layer (PL), which is about $30 \mathrm{~cm}$ thick and made of sand and gravel $(n>0.39)$. The sand used for the construction has a $\mathrm{D}_{10}$, or grain diameter at $10 \%$ (in dry mass) passing, between 0.06 and $0.15 \mathrm{~mm}$, and a coefficient of uniformity $\mathrm{C}_{U}$, corresponding to the ratio of $\mathrm{D} 60$ by D10, between 2.5 and 3.3. The silt has a $\mathrm{D}_{10}$ of approximately $0.0015 \mathrm{~mm}$ and $\mathrm{a} \mathrm{C}_{\mathrm{U}}$ of 6.1 [25].

Since 1999, native vegetation has been growing on the site, which has returned to a semi-natural state. The site is surrounded by a mixed forest in the balsam fir-yellow birch domain [61], close to a mature jack pine plantation [22]. Colonization of the CCBE by native vegetation was studied from 2003 to 2008 [15]. It was shown that CCBEs, e.g., open space with a water saturated layer of substrate, are attractive ecological conditions for Salix sp. and Alnus sp. colonization. Populus spp. were also present but showed a lower vegetation cover value than Alnus and Salix sp. The average daily temperature ranges between $-15^{\circ} \mathrm{C}$ in January and $18^{\circ} \mathrm{C}$ in July with monthly precipitation ranging between 
$36 \mathrm{~mm}$ (February) and $96 \mathrm{~mm}$ (August) [62]. The water table can reach $2 \mathrm{~m}$ deep in the southern portion of the CCBE but is close to the surface in the northern part of it [63].

\subsection{Experimental Design}

Data gathering was performed in 2015 and 2016, during which dominant plant species as well as their cover and density levels were investigated. In 2015, twelve north-south transects of $50 \mathrm{~m}$ ( 4 transects in high water table zone, 4 transects in intermediate water table zone, and 4 transects in low water table zone) were done on site in July (Figures 1 and 2A), at the maximum aboveground development of the vegetation.
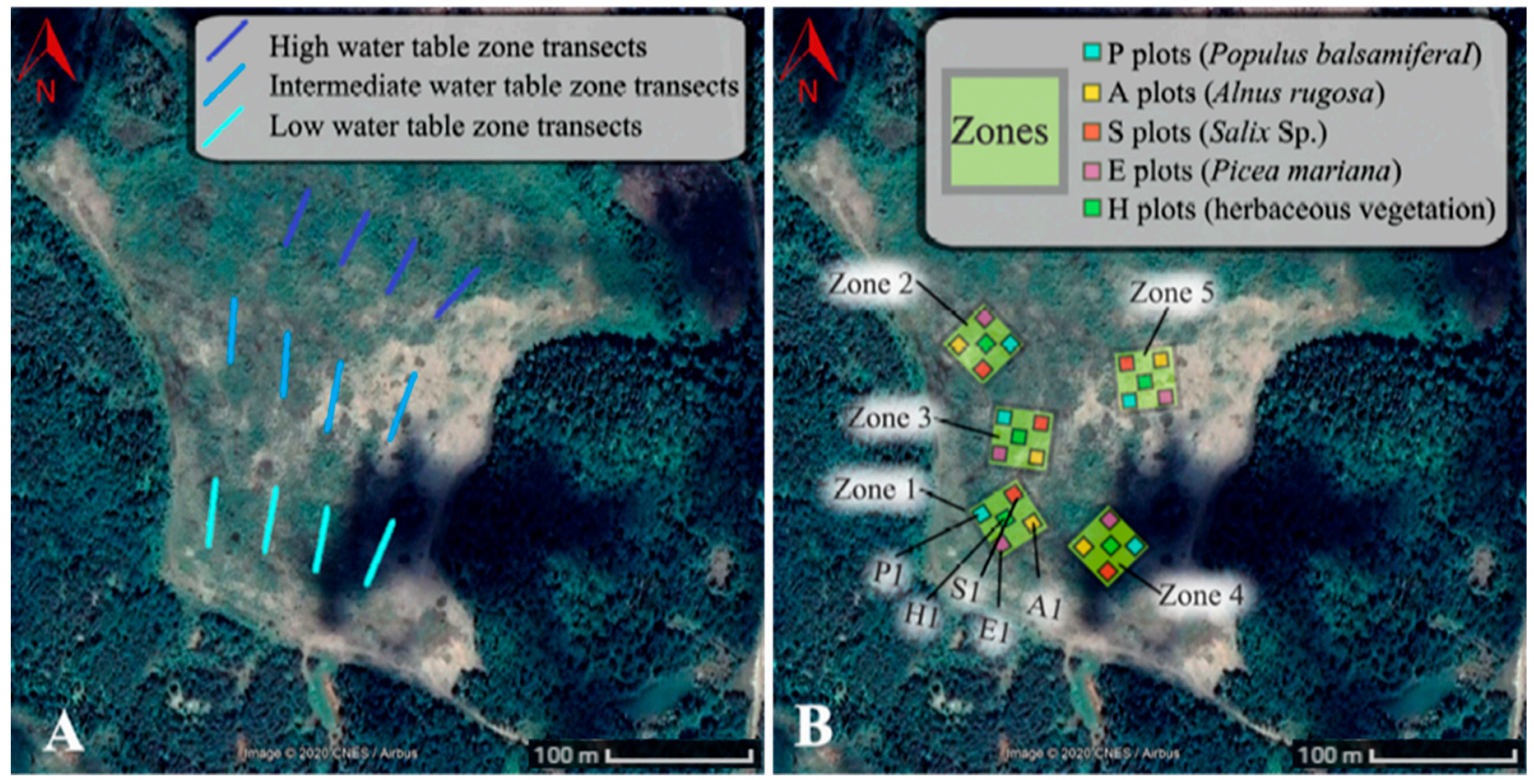

Figure 1. Position of monitoring transect (A) and zones and plots (B) on the Lorraine capillary barrier effect (CCBE) where the sampling was performed (image from Google, edited by authors).

In July 2016, five square monitoring zones $(50$ by $50 \mathrm{~m}$ ) were randomly selected in the southern portion of the CCBE where the water table is low (deeper than $70 \mathrm{~cm}$ ) (Figures 1 and 2E). They were numbered from 1 to 5 , and in each zone, five plots corresponding to five different vegetation types were randomly selected (Figure 2F). The five vegetation types corresponded to one of the four selected dominant woody species [Populus balsamifera (P plots), Alnus rugosa (A plots), Salix sp. (S plots), and Picea mariana (E plots for the French name of Picea mariana, "épinette")] or to dominant herbaceous vegetation (H plots). All plots dominated by a woody species needed to have at least one individual of the selected species with a minimum age of five years. This individual was considered the plot's main individual. Other species could also be found on each plot, but the targeted species were clearly dominant $(>50 \%)$ in terms of aboveground biomass. The plots were centered on the main individual and were $2 \mathrm{~m} \times 2 \mathrm{~m}$ in size. This $4 \mathrm{~m}^{2}$ surface contained at least all the aboveground biomass of the main individual whatever the considered species. 


\subsection{Measurements, Sampling, and Analyses}

\subsubsection{Aboveground Vegetation}

During July 2015, vegetation cover was measured using the point intercept method [64] with one point each $10 \mathrm{~cm}$ ( 500 measurements by transect) (Figure 2B). The contribution of each plant species or functional group to the total cover on a transect was calculated as:

$$
\frac{\text { Number of contacts by specie of interest }}{\sum \text { Contacts of each species }}
$$

Furthermore, $6 \mathrm{~m}^{2}$ circular plots were placed every $5 \mathrm{~m}$ along the transects (10 plots per transect for a total of 120 plots) (Figure 2C). These plots were used to calculate the density (number of individuals $/ \mathrm{m}^{2}$ ) and the contribution (\%) of each woody species to the density (Equation (2)).

$$
\frac{\text { Number of individuals of specie of interest }}{\sum \text { Nomber of individuals of each species }}
$$

For four woody species (Picea mariana, Populus balsamifera, Populus tremuloides, and Salix sp.), two individuals of mean representative height were randomly sampled on each transect. By counting the annual growth rings on crosscuts, the age of the main shoot (just above the hypocotyl) and the root system (first roots under the hypocotyl) was determined (Figure 2D).

In 2016, all aboveground vegetation was harvested by hand in the 25 plots that were established that year ( 5 by vegetation type in each zone) and separated into woody and herbaceous categories (Figure 2G). The herbaceous species were sorted by species, dried at $65^{\circ} \mathrm{C}$ for $48 \mathrm{~h}$, and weighed. For the woody species, the shoot maximal height $(\mathrm{cm})$ and diameter $(\mathrm{mm})$ at the base of each individual were measured on site and then the plant was harvested. Leaves and needles were then removed. Leaves were analyzed using a LI-3100C Area Meter (LI-COR, Lincoln, NE, USA) to measure total leaf area $\left(\mathrm{m}^{2}\right)$. Then, leaves and needles were dried at $65^{\circ} \mathrm{C}$ for $48 \mathrm{~h}$ and weighed. The woody mass and herbaceous mass were then divided by the area of the plot to get the mass $(\mathrm{g})$ per $\mathrm{m}^{2}$.

\subsubsection{Belowground Vegetation}

On each $2 \mathrm{~m} \times 2 \mathrm{~m}$ plot, after the aboveground vegetation was harvested, the PL was removed using an excavator to give access to the MRL (Figure $2 \mathrm{H}$ ). Three locations were selected for core sampling: one directly in the center of the plot (under the main individual) and two on the opposite sides of the first sampling hole, at a distance of $50 \mathrm{~cm}$ from its center (Figure 2I). These samples were harvested using a core sampler, producing samples of $8 \mathrm{~cm}$ in diameter and $10 \mathrm{~cm}$ in height. At each location, three samples were taken at different depths, one at the top of the MRL (0-10 cm sample), one at a depth of $20 \mathrm{~cm}$, and one at a depth of $35 \mathrm{~cm}$ (20-30 cm samples and 35-45 cm samples, respectively). Due to the degree of compaction and degree of saturation of the deeper part of the MRL, some samples were difficult to obtain and are missing. Three to 9 cores per plot were sampled, for a total of 145 samples. Samples were washed and sieved to collect the roots, which were then scanned (Figure 2J). The produced images were analyzed using WinRHIZO (regular version, Regent Instruments Inc., Sainte-Foy, QC, Canada). This software provides a variety of root parameters such as the root volume density, RVD (total root volume/volume of soil sample), root length density, RLD (total root length/volume of soil sample), and mean root diameter. Roots were then oven-dried for $48 \mathrm{~h}$ at $65{ }^{\circ} \mathrm{C}$ to measure the dry root mass of the samples and calculate the root mass density, RMD (total root mass/volume of soil sample). Finally, to better understand the relation between aboveground and belowground vegetation parameters, a ratio of aboveground to belowground vegetation was used. Total aboveground vegetation was transformed in $\mathrm{g} / \mathrm{m}^{2}$ for each plot and divided by the mean RMD in the MRL (combined sampling depths and locations) $\left(\mathrm{g} / \mathrm{m}^{3}\right)$ to get this aboveground to belowground vegetation ratio $(\mathrm{Av} / \mathrm{Bv})$. This calculation was used because the more commonly used "root to shoot 
ratio" was not available since the PL was not sampled, and thus part of the root system was absent from the analysis.

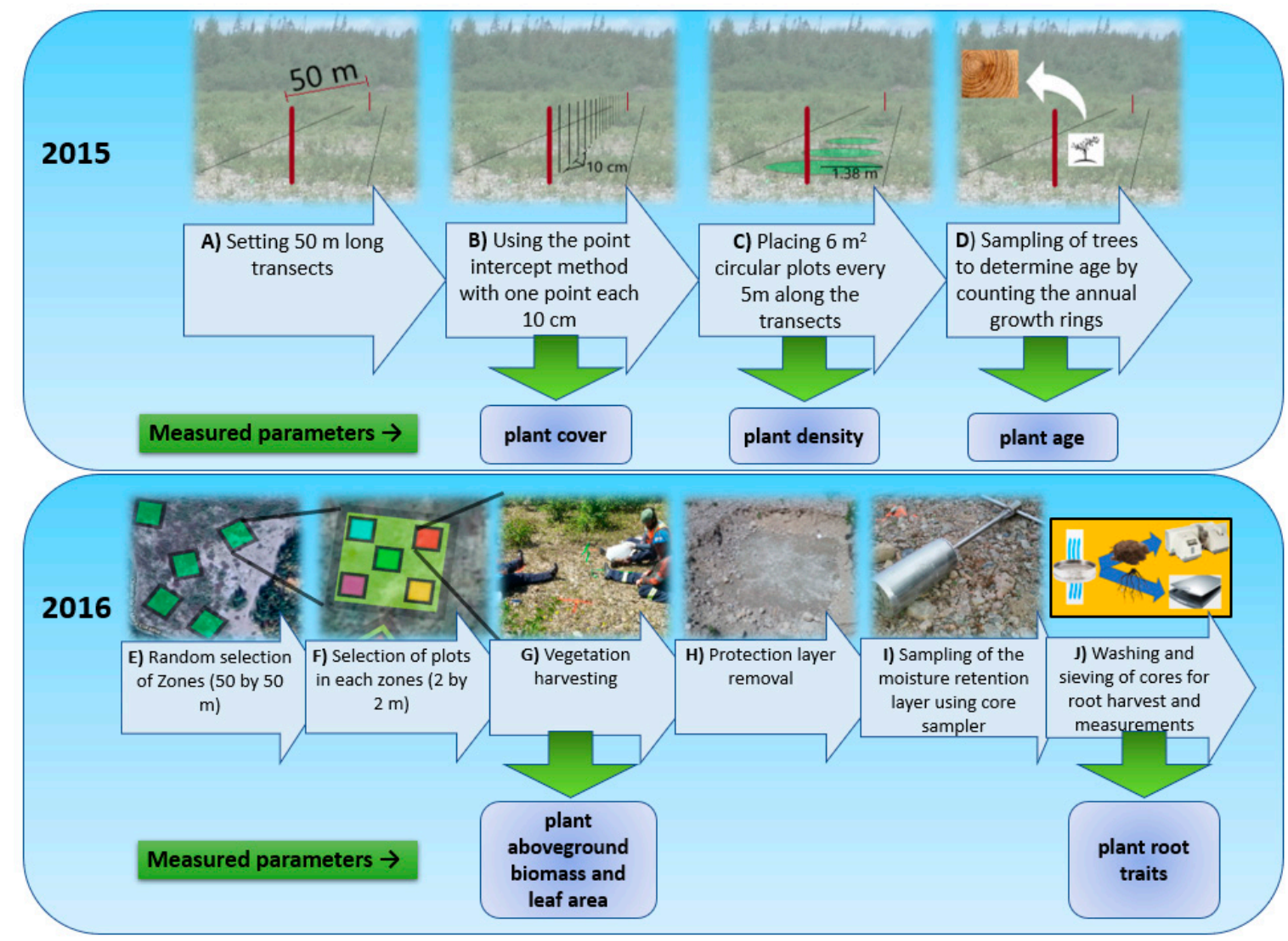

Figure 2. Methodological diagram showing the sequence of work and the measured parameters at each step that were done on the Lorraine mine site. (A) Transect setting (B) Plant cover measurement on transect (C) Plant density measurement on transect (D) Sampling of trees to determine plant age (E) Random selection of study zones (F) Selection of species plots (G) Harvesting of aboveground vegetation (H) Removing of the protection layer of the CCBE (I) Sampling of the moisture retention layer using a core sampler (J) Plant root analysis in lab.

\subsection{Statistical Analyses}

Belowground and aboveground plant data were statistically analyzed using the OriginPro 2019 software (OriginLab, Northampton, MA, USA). Linear correlations and regressions were done to assess the relationships between the different parameters, specifically analyzing belowground parameters (RLD, RVD, RMD, average root diameter) with aboveground parameters (woody biomass, herbaceous biomass, height, leaf area, leaf biomass). The Pearson test was used to discriminate the significant relationships using a signification threshold of 0.05. To deepen the analysis, ANOVAs were also performed. Aboveground parameter data showed normality and variance homogeneity and did not need to be transformed. However, root parameters were normalized to allow for ANOVA testing. Two way ANOVAs were performed on RLD, RVD, RMD, average root diameter, woody species biomass, herbaceous species biomass, total biomass, total leaf area, and Av/Bv using zone as the random factor and plot type (A, E, H, P and S) as the fixed factor. A three-way ANOVA was used to study the effect of sampling depth and plant type (fixed factors) with zone as the random factor, on the root parameters. In all cases, means comparisons were done using Fisher's test with an $\alpha$ of 0.05. 


\section{Results}

\subsection{Vegetation Colonization}

Fifteen different woody species were present on site (Salix sp., Abies balsamea L. (Mill.), Larix laricina (Du Roi) K. Koch, Alnus rugosa (Du Roi) Spreng, Populus balsamifera L., Pinus banksiana Lamb., Pinus resinosa Aiton, Populus tremuloides Michx, Betula papyrifera Marshall, Picea mariana (Mill.) Britton, Prunus pensylvanica L. f., Pinus strobus L., Comptonia peregrina L., Vaccinium sp., Kalmia sp.). The woody plants were the most represented on the CCBE with a total contribution to plant cover of 51 to $75 \%$ (Table 1). Five different woody species dominated the site: Populus balsamifera, Alnus rugosa, Populus tremuloides, Salix sp., and Picea mariana, each contributing more than 10\% to density (Figure 3). Four of these species were selected for the continuation of this study, including one per genus. Populus balsamifera was selected over tremuloides due to a higher density of individuals on site.

Table 1. Vegetation cover (\%), density (Number of individuals by $\mathrm{m}^{2}$ ), and contribution to cover and density (\%) in July 2015 among zones of differing water table level (high, intermediate, low) on the CCBE constructed on the Lorraine abandoned mine site. Mean (S.E.), $\mathrm{n}=4$.

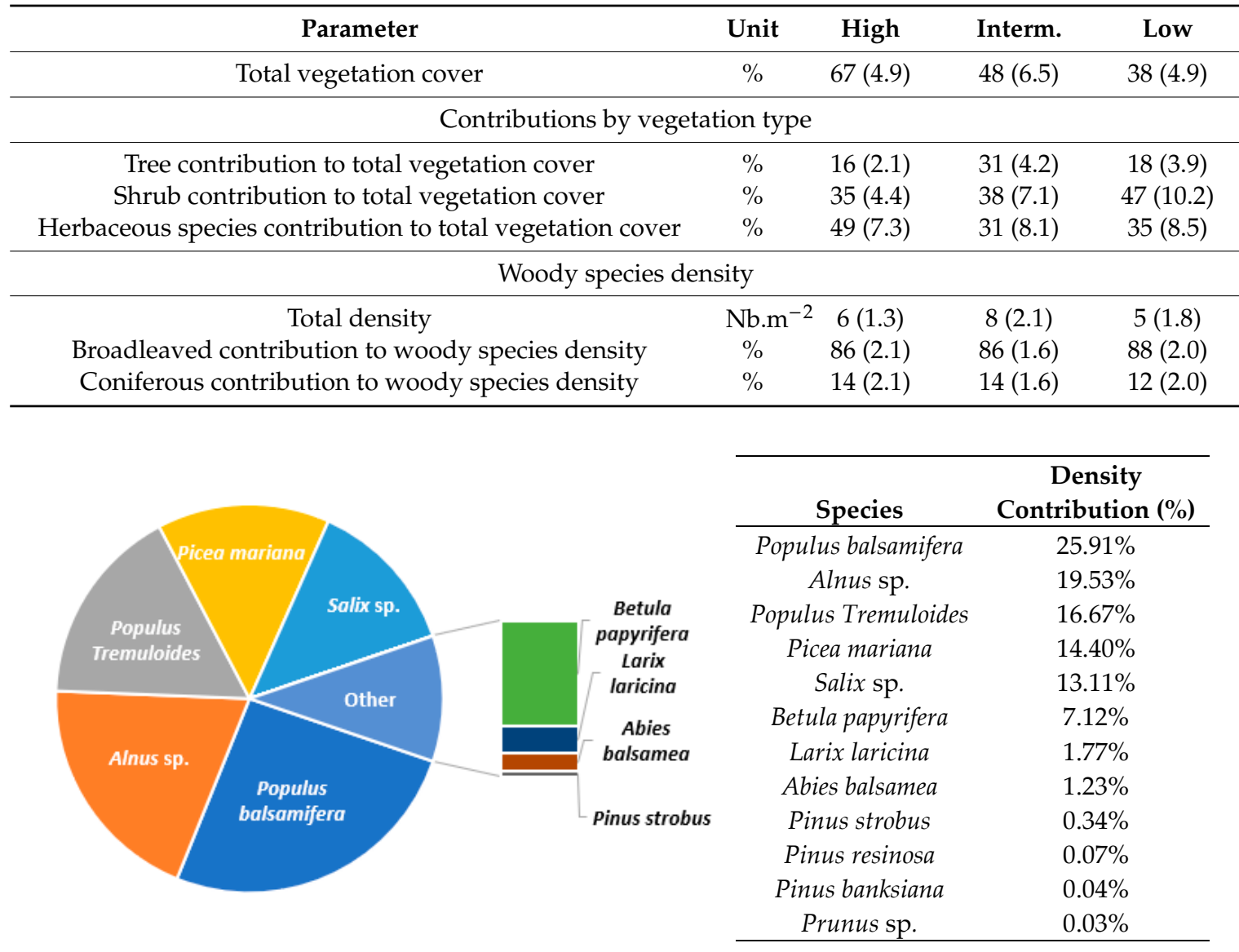

Figure 3. Average contribution of different woody species to the total density of woody species (\%) occurring in July 2015 on the cover with capillary barrier effect constructed on the Lorraine abandoned mine site.

The woody species mean density reached five to eight individuals per square meters and, except for Picea mariana, conifers were less represented than broadleaved species, since broadleaved accounted for 86 to $88 \%$ of the woody individuals (Table 1 ). Total vegetation cover varied between $38 \%$ and $67 \%$, depending on the water table depth (Table 1). Total vegetation cover included herbaceous cover, shrubs (Salix sp. and Alnus rugosa were considered shrubs), and trees (including Populus balsamifera 
and Picea mariana). The low value of vegetation cover does not seem to be attributable to the young age of the woody species. Indeed, it was shown that the woody species had time to colonize and grow on the PL with the mean age of woody species being greater than 6 years and some individuals being as old as the CCBE (Table 2). This means that some trees present on site had started growing some 15 years before the present measurement and a higher vegetation cover could have been expected.

Table 2. Mean and maximal ages of the shoot of four woody species occurring in July 2015 on the CCBE constructed on the Lorraine abandoned mine site. Mean (S.E.), $\mathrm{n}=24$. Means that do not differ at the 0.05 level are noted with the same letter.

\begin{tabular}{ccc}
\hline Species & $\begin{array}{c}\text { Maximal Age of the Shoots in } \\
\text { 2015 (Year) }\end{array}$ & $\begin{array}{c}\text { Mean Age of the Shoots in } \\
\text { 2015 (Year) }\end{array}$ \\
\hline Salix sp. & 14 & $7.3(0.6) \mathrm{a}$ \\
Populus balsamifera & 11 & $5.6(0.7) \mathrm{a}$ \\
Populus tremuloides & 13 & $6.8(0.5) \mathrm{a}$ \\
Picea mariana & 16 & $10.7(0.6) \mathrm{b}$ \\
\hline
\end{tabular}

\subsection{Aboveground Parameters}

Of the four main plant species, the aboveground development of 12 to 35 different individuals were characterised, depending on the specie (Table 3). However, the species did not statistically influence the aboveground parameters measured. Aboveground parameters showed a high variability across plots (Table 4). On all plots, the main woody individual represented more than $31 \%$ (with a mean of $66 \%$, S.E. $=6 \%$ ) of the total woody biomass. The only exception was the 44 plot, where a particularly massive Alnus sp. was found, bringing Salix sp. specific woody biomass to $8 \%$ of the woody biomass on this plot. The four herbaceous plots had woody species present, but all were small. Woody biomass on those plots was either low $\left(\mathrm{H} 1=10 \mathrm{~g} / \mathrm{m}^{2}, \mathrm{H} 3\right.$ and $\left.\mathrm{H} 5=1 \mathrm{~g} / \mathrm{m}^{2}\right)$ or in the mid-range for $\mathrm{H} 2 \mathrm{at} 34 \mathrm{~g} / \mathrm{m}^{2}$. On all plots, the measured herbaceous biomass and woody biomass showed similar variations (Table 4).

Table 3. Minimal, mean, and maximal height, leaf biomass, leaf area and biomass of every sampled individual of the four main studied species on the cover with capillary barrier effect constructed on the Lorraine abandoned mine site. Mean (S.E.). P. mariana has no leaf area presented because leaf area was only measured for broadleaved species.

\begin{tabular}{|c|c|c|c|c|}
\hline Parameter & Number of Individuals & Minimum & Mean & Maximum \\
\hline \multicolumn{5}{|c|}{ Height $(\mathrm{cm})$} \\
\hline Alnus sp. & $\mathrm{n}=25$ & 10.2 & $96.7(16.3)$ & 255.5 \\
\hline P. mariana & $\mathrm{n}=20$ & 8.9 & $29.8(4.3)$ & 78.7 \\
\hline Populus sp. & $\mathrm{n}=35$ & 10.0 & $61.8(10.8)$ & 234.0 \\
\hline Salix sp. & $\mathrm{n}=12$ & 22.0 & $101.7(27.3)$ & 261.6 \\
\hline \multicolumn{5}{|c|}{ Leaf biomass (g) } \\
\hline Alnus sp. & $\mathrm{n}=25$ & 0.3 & $76.8(19)$ & 371.6 \\
\hline P. mariana & $\mathrm{n}=20$ & 0.1 & $36.9(11.1)$ & 175.0 \\
\hline Populus sp. & $\mathrm{n}=35$ & 0.1 & $42.5(14.6)$ & 400.0 \\
\hline Salix sp. & $\mathrm{n}=12$ & 0.6 & $46.9(23.5)$ & 280.0 \\
\hline \multicolumn{5}{|c|}{ Leaf area $\left(\mathrm{m}^{2}\right)$} \\
\hline Alnus sp. & $\mathrm{n}=25$ & 0.002 & $1.02(0.27)$ & 5.36 \\
\hline P. mariana & $\mathrm{n}=20$ & N.A. & N.A. & N.A. \\
\hline Populus sp. & $\mathrm{n}=35$ & 0.002 & $0.60(0.21)$ & 6.32 \\
\hline Salix sp. & $\mathrm{n}=12$ & 0.004 & $0.58(0.26)$ & 2.80 \\
\hline \multicolumn{5}{|c|}{ Biomass (g) } \\
\hline Alnus sp. & $\mathrm{n}=25$ & 0.36 & $98.2(22.7)$ & 408 \\
\hline P. mariana & $\mathrm{n}=20$ & 0.13 & $39.9(11.1)$ & 176 \\
\hline Populus sp. & $\mathrm{n}=35$ & 0.11 & $57(17.5)$ & 442 \\
\hline Salix sp. & $\mathrm{n}=12$ & 2.44 & $72.3(32.3)$ & 359 \\
\hline
\end{tabular}

Note: N.A.: not applicable. 
Table 4. Minimal, mean, and maximal woody, herbaceous and total biomass on the 25 different plots on the cover with capillary barrier effect constructed on the Lorraine abandoned mine site. Mean (S.E.), $\mathrm{n}=25$.

\begin{tabular}{ccccc}
\hline Parameter & Unit & Minimum & Mean & Maximum \\
\hline Woody biomass & $\mathrm{g} / \mathrm{m}^{2}$ & 0 & $66(14)$ & 263 \\
Herbaceous biomass & $\mathrm{g} / \mathrm{m}^{2}$ & 0.7 & $41(12)$ & 160 \\
Total biomass & $\mathrm{g} / \mathrm{m}^{2}$ & 1.4 & $101(15)$ & 284 \\
\hline
\end{tabular}

Table 4 shows a high variability in aboveground parameters from one plot to another, especially in view of the high standard error around the means. Some standard errors were bigger than the mean of the parameter. However, some plot types still statistically differed from others. The first statistical observation was that the mean aboveground biomass of woody species was at least five times higher in plots dominated by Alnus and Salix compared to plots dominated by Picea and herbaceous species ( $p=0.02$, Figure 4). Other aboveground vegetation parameters [main individual's aboveground biomass, herbaceous biomass, total biomass (Figure 4), and total leaf area and biomass] were not significantly affected by the plot's dominant species.

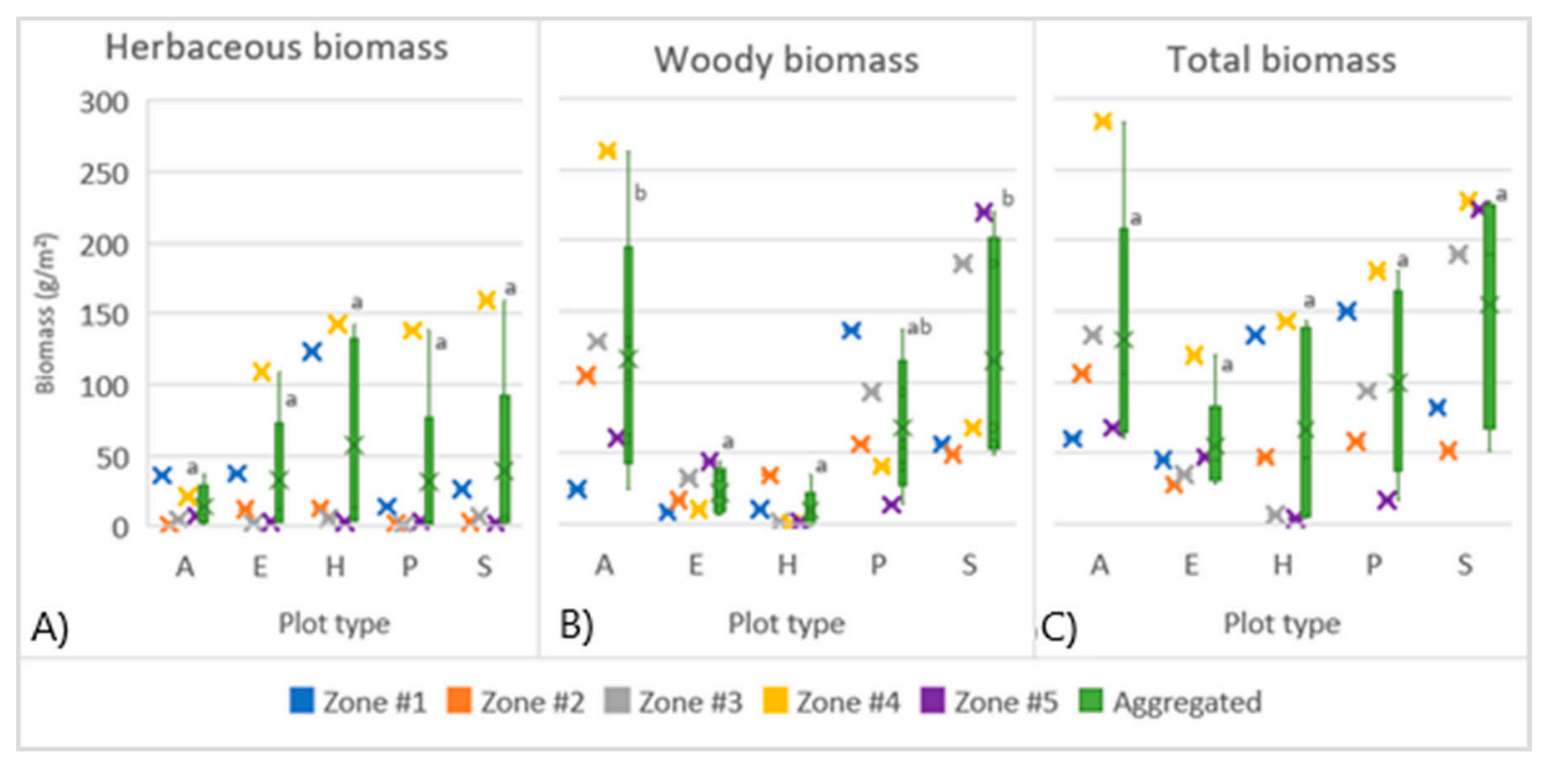

Figure 4. Aboveground biomass (A) from herbaceous species, (B) from woody species and (C) total plant biomass for each plot type [Alnus rugosa (A), Picea mariana (E), Herbaceous (H), Populus balsamifera (P), and Salix Sp. (S)] and Zone (1 to 5). Crosses represent specific plot points with a color for each zone. Boxplots represent the aggregated results for each plot type $(n=5)$. On the aggregated results bars, means that do not differ at the 0.05 level are noted with the same letter $(a<b)$

\subsection{Belowground Parameters}

Like aboveground parameters, belowground parameters varied greatly across plots, which is illustrated by high S.E. around means (Table 5). Minimum RLD, RVD, and RMD were $8.2 \mathrm{~m} / \mathrm{m}^{3}$, $0.2 \mathrm{~cm}^{3} / \mathrm{m}^{3}$, and $0.2 \mathrm{~g} / \mathrm{m}^{3}$, respectively. Maximum RLD, RVD, and RMD were $5301 \mathrm{~m} / \mathrm{m}^{3}, 1383 \mathrm{~cm}^{3} / \mathrm{m}^{3}$, and $239.1 \mathrm{~g} / \mathrm{m}^{3}$, respectively, and were all encountered at the 0 to $10 \mathrm{~cm}$ sampling depth (Table 5). Both RLD and RMD spanned across values differing by two orders of magnitude (maximums being an average of 450 times bigger than their respective minimums), but RVD had the largest range with the highest value point being more than 2000 times larger than the minimum value. However, plot type and sampling depth could explain some of the variability. 
Table 5. Minimal, mean, and maximal root length density (RLD), root volume density (RVD), and root mass density (RMD) aggregated by sampling depths under the 25 plots of the cover with capillary barrier effect constructed on the Lorraine abandoned mine site. Mean (S.E.), $\mathrm{n}=64$ for $0-10$ depth, $\mathrm{n}=47$ for $20-30$ depth, $\mathrm{n}=33$ for $35-45$ depth.

\begin{tabular}{cccccc}
\hline Depth & Parameter & Unit & Minimum & Mean & Maximum \\
\hline \multirow{3}{*}{$0-10 \mathrm{~cm}$} & RLD & $\mathrm{m} / \mathrm{m}^{3}$ & 17 & $1489(184)$ & 5301 \\
& RVD & $\mathrm{cm}^{3} / \mathrm{m}^{3}$ & 0.6 & $195(35)$ & 1383 \\
& RMD & $\mathrm{g} / \mathrm{m}^{3}$ & 0.2 & $31(5)$ & 239.1 \\
\hline \multirow{3}{*}{$20-30 \mathrm{~cm}$} & RLD & $\mathrm{m} / \mathrm{m}^{3}$ & 8.2 & $130(20)$ & 610 \\
& RVD & $\mathrm{cm}^{3} / \mathrm{m}^{3}$ & 0.2 & $21(6)$ & 231 \\
& RMD & $\mathrm{g} / \mathrm{m}^{3}$ & 0.2 & $4.1(1)$ & 29 \\
\hline \multirow{3}{*}{$35-45 \mathrm{~cm}$} & RLD & $\mathrm{m} / \mathrm{m}^{3}$ & 17 & $97(18)$ & 512 \\
& RVD & $\mathrm{cm}^{3} / \mathrm{m}^{3}$ & 0.6 & $12(3)$ & 79 \\
\hline
\end{tabular}

The root colonization intensity in terms of mean RLD, RVD, and RMD were, respectively, eleven, nine, and seven times higher in the top $10 \mathrm{~cm}$ of the MRL (all p < 0.001, Figure 5) compared to deeper sampling depths for all plot types and zones. That is, there was no significant interaction between sampling depth and plot type or zone. Since the deeper parts of the MRL were sparsely colonized, the analyses of the plot type effect were performed using the top samples $(0-10 \mathrm{~cm})$. Thus, all further results shown here present data from the 0 to $10 \mathrm{~cm}$ depth samples.
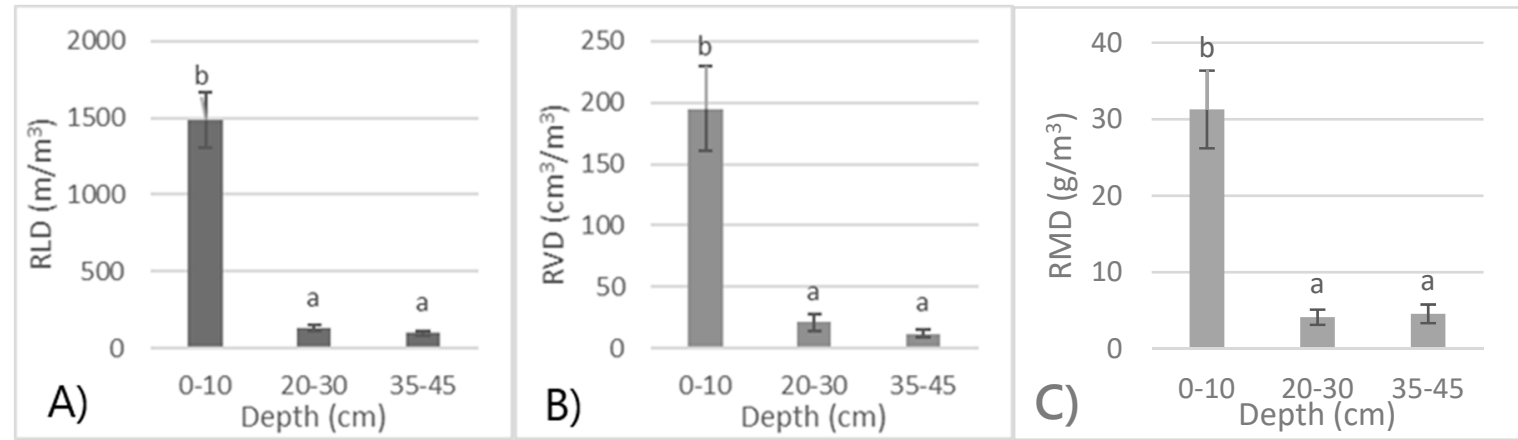

Figure 5. (A) Root length density (RLD), (B) root volume density (RVD), and (C) root mass density (RMD) for the different plots grouped by sampling depth. Mean $(n \geq 33)$. Bars denote SE. Means that do not differ at the 0.05 level are noted with the same letter $(a<b)$.

The mean RLD was two times higher in plots dominated by Salix compared to plots dominated by Alnus, herbaceous plants, and Picea ( $p=0.04$, Figure 6), while the mean RVD and RMD did not differ at the 0.05 level across plot types (Figure 6). For all plot types, the variability across sampling locations was high (except for E plots) and in the same range as across sampling zones (Figure 7). For example, in the S1 plot, the RLD values were $1074 \mathrm{~m} / \mathrm{m}^{3}, 1491 \mathrm{~m} / \mathrm{m}^{3}$, and $5301 \mathrm{~m} / \mathrm{m}^{3}$ at locations $50 \mathrm{~cm}$ from each other. Finally, the root average diameters were not impacted by plot type or sampling depth $(p>0.05)$. To deepen the analysis, the data were separated into two categories: roots with diameters over $1 \mathrm{~mm}$ (coarse roots), and roots with diameters under $1 \mathrm{~mm}$ (fine roots) (Figure 6). Coarse roots length represented $15 \%$ (S.E. $=1.6 \%$ ) of total length of roots and was not impacted by plot type or sampling depth $(p>0.05)$. The same lack of impact was observed on the coarse roots' length density. 

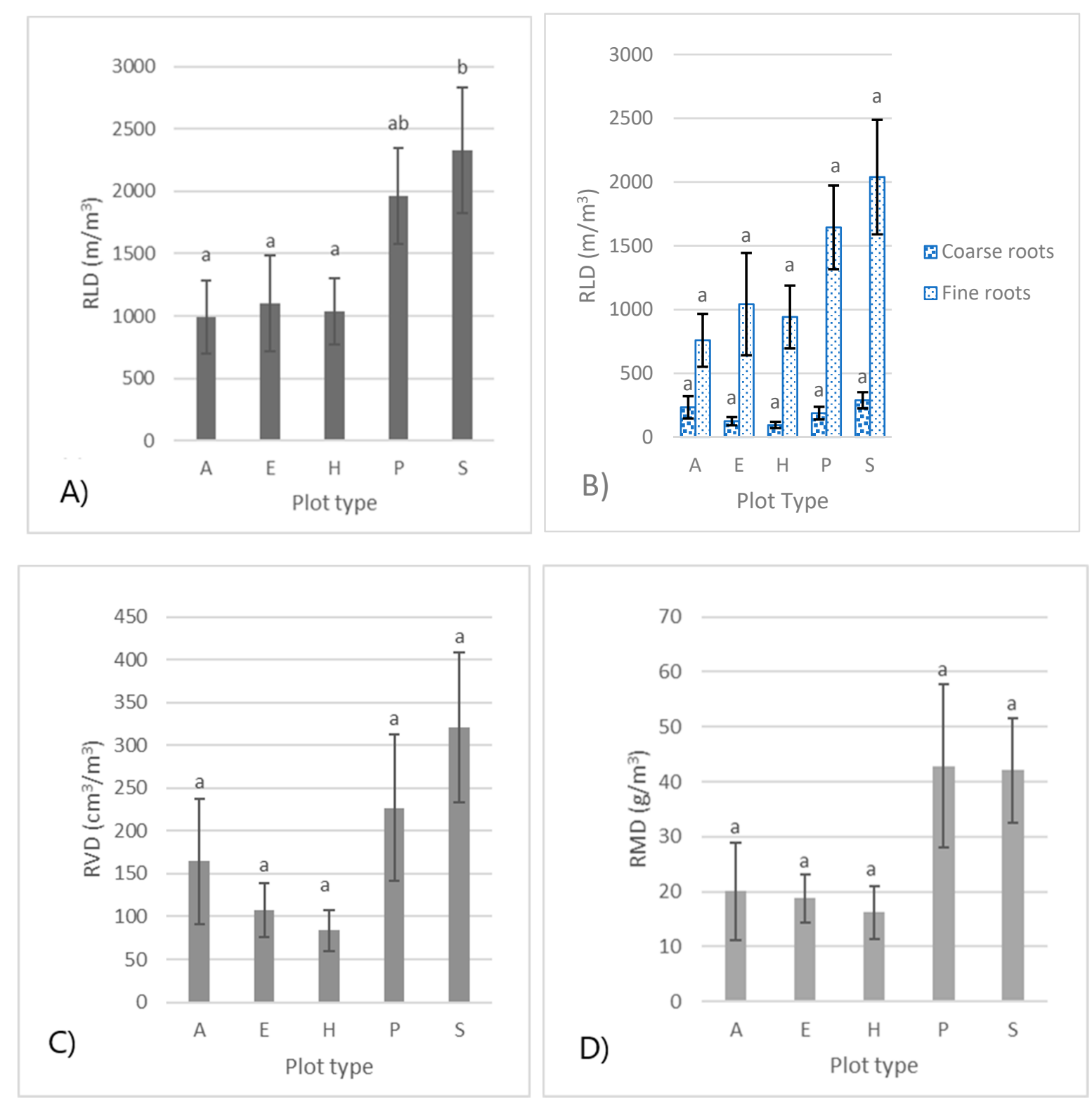

Figure 6. (A) Root length density (RLD); (B) RLD divided into fine root length density (fine dotted bars) and coarse root length density (coarse dotted bars); (C) root volume density; and (D) root mass density (RMD) at 0-10 cm depth for each plot type [Alnus rugosa (A), Picea mariana (E), Herbaceous (H), Populus balsamifera $(\mathrm{P})$ and Salix Sp. (S)].Mean $(\mathrm{n} \geq 12)$. Bars denote S.E. Means that do not differ at the 0.05 level are noted with the same letter $(\mathrm{a}<\mathrm{b})$ 


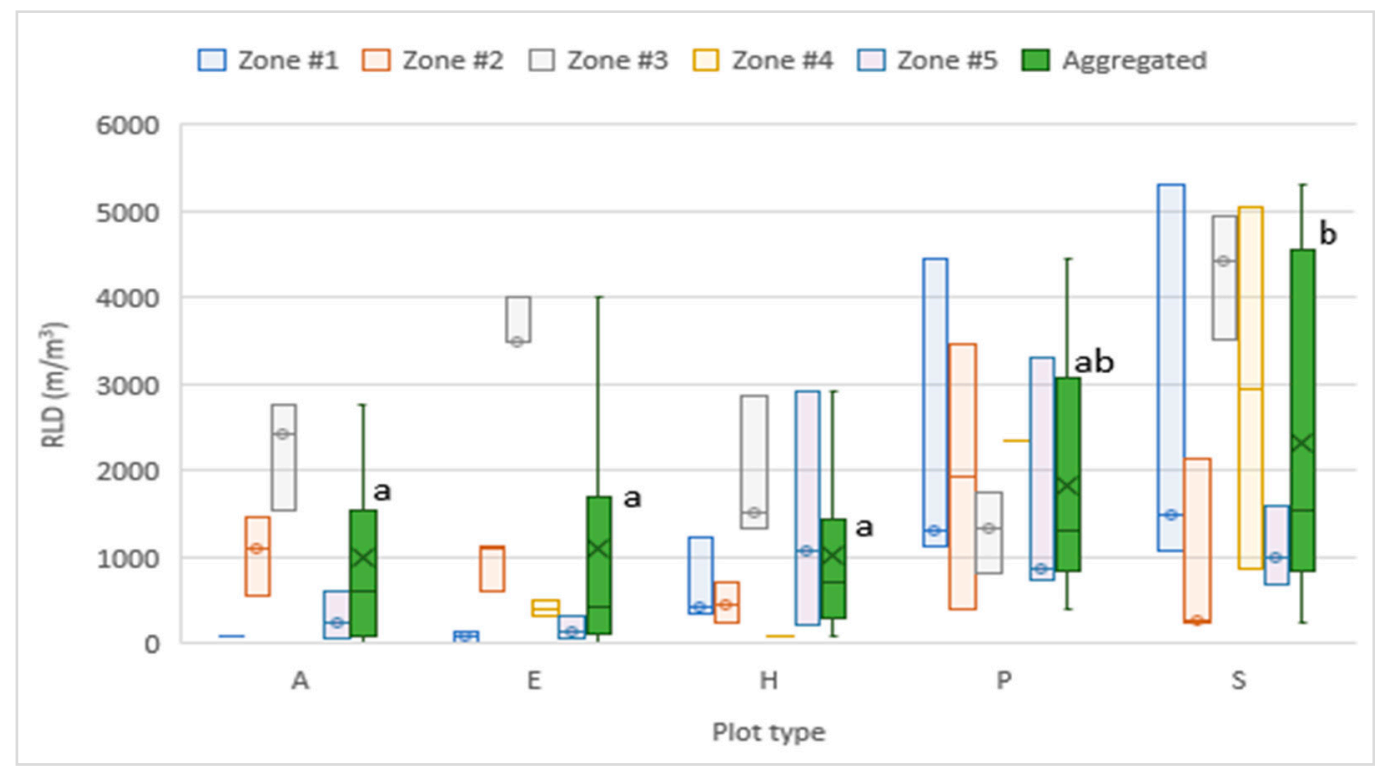

Figure 7. Root length density (RLD) at 0-10 cm depth of MRL for each plot type [Alnus rugosa (A), Picea mariana (E), Herbaceous (H), Populus balsamifera (P) and Salix Sp. (S)] and each Zone (1, 2, 3, 4, and 5). Lines represent plots with one data point. Box without middle dot represent plots with two data points. Box with dots represent plots with all three data points. The green boxes are the aggregated RLD values for all plots of the presented type, $n \geq 11$.

\subsection{Aboveground and Belowground Interactions}

The mean $\mathrm{Av} / \mathrm{Bv}$ of Alnus-dominated plots was ten times higher than the Picea mariana, Populus balsamifera, and Salix Sp. plots $(p=0.04$, Figure 8$)$. Most linear regression tests between aboveground and belowground parameters were not statistically significant due to the high variability found in the data, as shown in Figure 7. However, the aboveground woody biomass had a slight positive linear relationship with the RVD in the MRL with a Pearson correlation factor of 0.45 ( $p$-value $=0.03$ ). Moreover, by removing Alnus plots from the previous analysis, the relationship became stronger with a Pearson correlation factor of 0.76 ( $p$-value $<0.001)$. Some weaker relations could be found using an $\alpha$ threshold of 0.10 and are presented in Table 6 .

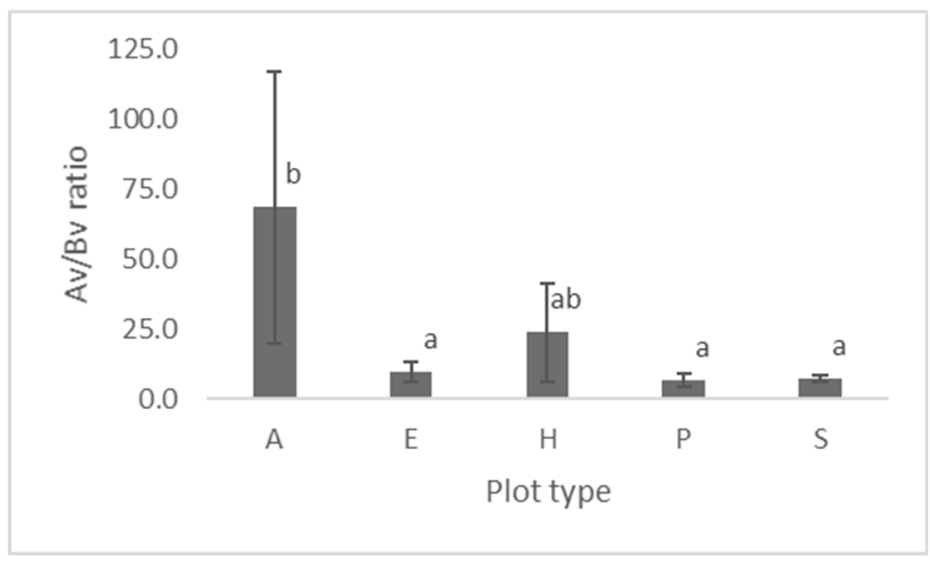

Figure 8. Aboveground vegetation on belowground vegetation ratio ( $\mathrm{Av} / \mathrm{Bv})$ for each plot types [Alnus rugosa (A), Picea mariana (E), Herbaceous (H), Populus balsamifera (P), and Salix Sp. (S)]. Means ( $=5)$. Bars denote S.E.\# Means that do not differ at the 0.05 level are noted with the same letter $(a<b)$. 
Table 6. Relations between aboveground and belowground parameters that are significant if using $\alpha=0.10$.

\begin{tabular}{ccccc}
\hline 1st Parameter & 2nd Parameter & n & \multicolumn{2}{c}{ Correlation Statistics } \\
\hline Aboveground Woody Biomass $\left(\mathrm{g} / \mathrm{m}^{2}\right)$ & Mean RMD $\left(\mathrm{g} / \mathrm{m}^{3}\right)$ & 25 & Pearson $\mathrm{r}$ & 0.34 \\
\hline Mean Woody leaf area $\left(\mathrm{cm}^{2}\right)$ & Log mean RLD $\left(\mathrm{m} / \mathrm{m}^{3}\right)$ & 25 & Pearson r & 0.50 \\
\hline Aboveground Woody Biomass $\left(\mathrm{g} / \mathrm{m}^{2}\right)$ & Mean RVD $\left(\mathrm{cm}^{3} / \mathrm{m}^{3}\right)$ & 25 & Pearson r & 0.45 \\
\hline
\end{tabular}

\section{Discussion}

\subsection{Vegetation Colonization on the CCBE}

The main species of trees found on the CCBE were Populus balsamifera (26\% contribution), Alnus sp. (20\% contribution), Populus Tremuloides (17\% contribution), Picea mariana (14\% contribution) and Salix sp. (13\% contribution). Together, they account for about $90 \%$ of all trees on site. The results showed that Alnus sp.-dominated and Salix sp.-dominated plots both presented a higher degree of aboveground woody biomass production on the CCBE. Their ability to fix nitrogen (Alnus sp.) and their resistance to low nutrient environment (Salix sp.) could also explain their increased growth. However, $P$. mariana is also included in the pioneer species for this CCBE, but presents a low level of biomass, which could be explained by the fact that $P$. mariana is a slow-growing species $[65,66]$ and was not expected to grow significantly, even if it was one of the first species to colonize the CCBE. These observations are in line with other works describing natural colonization over mining soil in boreal forest climate $[15,49,50]$. It is also interesting to notice the similitude between the vegetation present on the CCBE and the vegetation reported by other works made on glacier retreat sites [67].

Because it leaves coarse soils on which primary vegetation succession occurs [68,69], glacier retreat in Alaska could be a good analogue of an installed CCBE in the boreal or mixed forest zone. Indeed, the soil left by glacier retreat presents similar constraints to plant establishment, including a low water retention capacity [70,71] and low $\mathrm{N}$ and $\mathrm{C}$ concentrations [72]. Since the soil left by the retreat of a glacier has low nutrient concentrations, it is usually colonized by species with low nitrogen demand like Salix sp. [73] and associated with N-fixing bacteria such as Alnus sp. [69,74]. Further away from the glacier, at a location that represents a slightly later stage of succession, the nutrient concentrations of the soil increase. Species requiring more nutrients, such as Populus sp., are usually more represented there [73]. However, since the main water source (the glacier) is further away and the soil is made of coarse material, water is scarcer. In that case, water-stress-resistant species, such as Picea mariana, can also be seen [49]. As the CCBE ages, the same evolution from low nutrient to higher nutrient concentrations is likely to be observed.

It was also observed that the total vegetation cover was still low (from 38 to 67\%), despite some woody individuals being older than 10 years. Since the density of woody species was high (five to eight individuals $/ \mathrm{m}^{2}$ ), a higher degree of vegetation cover would have been expected. The low vegetation cover might be due, in part, to low water content in the PL for shallow-rooted plants, and to restricted seedling growth by nutrient limitations, especially nitrogen [75]. Indeed, the low level of soil $\mathrm{N}$ would limit the extension growth of vegetation [76]. Furthermore, if light is not a limiting factor such as on the present cover, $\mathrm{N}$ will limit plant growth but not survivability [77], producing low levels of vegetation cover for a relatively high level of woody species density. All these findings align well with previous work on vegetation succession after glacier retreat in a boreal or temperate mixed forest environment.

The main difference between the natural glacier retreat vegetation succession and what was observed here is the higher vegetation cover and the high density of Populus spp. In succession 
following a glacier retreat, the expected vegetation cover after 17 years is about $25 \%$ [67] which is under the 38 to $67 \%$ observed here.

The colonization success might be due to the proximity of mature forests to the CCBE, which would help garner seeds on the PL. Indeed, Picea mariana [78] and Alnus sp. [79] both have an estimated maximum seed dispersion distance of around $100 \mathrm{~m}$. However, it is understood that the bulk of the seeds will fall at a shorter range of about 20 to $30 \mathrm{~m}$ [80] and that almost no individuals will be found further away. Therefore, some woody species' colonization on a glacier retreat may be restricted to the area close to the remaining vegetation, including seed bearers. Whereas human-made disturbances occur on smaller areas and plant recolonization may less suffer from the distance from seed bearers.

\subsection{Species Root Depth Colonization}

Regarding the depth of root colonization, the results observed on the CCBE were opposite to what was predicted in the first hypothesis. Indeed, roots were found in the MRL under both woodyand herbaceous-dominated plots, which was not expected. When compared to other plot types, herbaceous-dominated plots were not statistically different in term of root colonization (RLD, RVD, and RMD). Even if herbaceous species usually have shallower rooting depth than woody species [16], colonization by herbaceous species roots as deep as $80 \mathrm{~cm}$ in natural soil [81] and up to $50 \mathrm{~cm}$ in mine tailings [82] has been observed. Moreover, tree roots could also be present in the MRL under herbaceous-dominated plots thanks to a greater horizontal growth of woody roots when reaching the interface of the water table $[83,84]$. The results did however follow what was predicted in the second hypothesis. The roots were able to reach the MRL, and root colonization sharply decreased with depth.

The top $10 \mathrm{~cm}$ of the MRL is well colonized by roots for all root parameters (RLD, RVD, RMD). However, the roots leave the deeper parts of the MRL only lightly colonized. When considering the impact those roots could have on the performance of the CCBE, the fact that the roots almost exclusively colonize the top $10 \mathrm{~cm}$ of the MRL could leave the CCBE's performance nearly intact. However, this might not hold true in the long term. One of the genera that could present a problem in the long run seems to be Salix sp. for three main reasons. First, plots dominated by Salix sp. presented a statistically higher RLD than the other species. Second, Salix sp. is known to have a high degree of water uptake [85], which could drain the MRL's water. Third, Salix sp. roots are able to survive in anoxic environments such as water-saturated MRL [41]. This could perhaps bring down the saturation level of the MRL and, given that the water in that layer both limits oxygen migration and root growth, could have severe consequences. On the other hand, as near-surface soils develop water holding capacity, water scarcity in the PL could be expected to decrease, possibly reducing rooting pressure on the MRL. Follow-up in the longer term may thus be needed.

\subsection{Correlation between Aboveground and Underground Vegetation}

The main finding is that aboveground vegetation parameters are not a good indicator of root colonization in the MRL. The relative lack of correlation between the aboveground and belowground levels could be explained by the previously mentioned root horizontal growth, which could create relatively homogenous root colonization across the site. However, some linear correlation with a low level of significance was found between RVD at the 0 to $10 \mathrm{~cm}$ depth of the MRL and the aboveground woody biomass. In this case, the interesting part of this relation is the rise of the correlation value if Alnus sp. is removed from the analysis. This increase in correlation shows a different dynamic between aboveground vegetation and MRL belowground vegetation specifically in Alnus sp.-dominated plots. Those plots were shown to have a very different ratio of aboveground vegetation to belowground vegetation. Alnus sp. presented high aboveground biomass and average (if not below average) belowground biomass in the MRL. This high level of aboveground biomass is explained by the fact that Alnus sp. can fix nitrogen, and thus was not limited in its growth by the lack of soil nitrogen. However, it is important to realize that Alnus sp. roots mainly colonize the top $30 \mathrm{~cm}$ of soil [86-88]. 
Since that top $30 \mathrm{~cm}$ represents the PL of the CCBE, it is quite possible that most of Alnus sp. root biomass was concentrated in the PL and thus did not appear in the present analysis.

\section{Conclusions}

This research studied the vegetation colonizing a 17-year-old CCBE, in the boreal mixed forest both at the above- and belowground levels. A better understanding of vegetation (especially root) colonization on an engineered cover such as this one is crucial to predict the long-term performance of the CCBE. It was found that vegetation succession on a CCBE in a mixed boreal forest biome resembles the succession pattern after a glacier retreat in the same biome. The main difference being that after 17 years, Populus sp. dominated the vegetation in terms of cover, but the overall cover of the vegetation remained low (mean cover 38-67\%). The root colonization of the MRL occurred under all types of vegetation tested, including herbaceous plants, but it was concentrated in the first $10 \mathrm{~cm}$, which may limit vegetation effect on the performance of the CCBE 17 years after its construction. Amongst the species that were analyzed, Salix sp. seemed to be of particular concern. Under Salix sp.-dominated plots, RLD was higher than under plots dominated by other woody species. Since Salix sp. can survive in an anoxic environment such as the saturated MRL, this could imply that, with time, an increase of RLD could be seen. This augmentation in the root colonization intensity could desaturate the top of the MRL, creating more favorable conditions (less anoxic) for roots of other species to colonize the MRL. Finally, it could be difficult to predict root colonization of the MRL based on aboveground vegetation development because above- and belowground (in the MRL) vegetation parameters did not appear well correlated. Therefore, further analysis of the impact of roots on a CCBE or other engineered cover should include sampling and analyses of root colonization of functional layers.

Author Contributions: Conceptualization, M.G.; methodology, M.G.; validation, A.P., M.G.; formal analysis, A.P. and M.G.; investigation, A.P.; data curation, M.G.; writing-original draft preparation, A.P.; writing-review and editing, A.P., M.G., B.B., and A.M.; visualization, A.P.; supervision, M.G.; project administration, M.G.; funding acquisition, B.B., M.G. and A.M. All authors have read and agreed to the published version of the manuscript.

Funding: This research was funded by the Fonds de Recherche du Québec sur la Nature et les Technologies (FRQNT): sustainable development of the mining sector program.

Acknowledgments: The authors thank the Research Institute on Mines and the Environment (RIME UQATPolytechnique, www.RIME-IRME.ca\$\delimiter"026E30F\$EN) for providing funding for this project. The authors also acknowledge the financial support of the Fonds de Recherche du Québec sur la Nature et les Technologies (FRQNT): sustainable development of the mining sector program, to perform this study, as well as the industrial partners of RIME-Polytechnique-UQAT. Finally, the authors thank the Ministère de l'Énergie et des Ressources naturelles of Quebec for granting them access to the Lorraine mine site.

Conflicts of Interest: The authors declare no conflict of interest. The funders had no role in the design of the study; in the collection, analyses, or interpretation of data; in the writing of the manuscript, or in the decision to publish the results.

\section{References}

1. Nicholson, R.V.; Gillham, R.W.; Cherry, J.A.; Reardon, E.J. Reduction of acid generation in mine tailings through the use of moisture-retaining cover layers as oxygen barriers. Can. Geotech. J. 1989, 26, 1-8. [CrossRef]

2. Yanful, E.K.; Bell, A.V.; Woyshner, M.R. Design of a composite soil cover for an experimental waste rock pile near Newcastle, New Brunswick, Canada. Can. Geotech. J. 1993, 30, 578-587. [CrossRef]

3. Yanful, E.K.; Riley, M.D.; Woyshner, M.R.; Duncan, J. Construction and Monitoring of a Composite Soil Cover on an Experimental Waste Rock Pile near Newcastle, New Brunswick, Canada. Can. Geotech. J. 1993, 30, 588-599. [CrossRef]

4. Yanful, E.K.; Simms, P.H.; Payant, S.C. Soil Covers for Controlling Acid Generation in Mine Tailings: A Laboratory Evaluation of the Physics and Geochemistry. Water Air Soil Pollut. 1999, 114, 347-375. [CrossRef]

5. Aubertin, M.; Chapuis, R.P.; Aachib, M.; Bussière, B.; Ricard, J.F.; Tremblay, L. Évaluation en Laboratoire de Barrières Sèches Construites à Partir de Résidus Miniers; NEDEM/MEND Report 2.22.2a, École Polytechnique de Montréal, Project CDT P1622; CD-ROM; Canada Centre for Mineral and Energy Technology (CANMET): Ottawa, ON, Canada, 1995. 
6. Aubertin, M.; Bussière, B.; Monzon, M.; Joanes, A.-M.; Gagnon, D.; Barbera, J.-M.; Aachib, M.; Bédard, C.; Chapuis, R.P.; Bernier, L. Étude sur les Barrières Sèches Construites à Partir des Résidus Miniers. Phase II-Essais en Place; NEDEM/MEND Report 2.22.2c, École Polytechnique de Montréal, Project CDT P1899; CD-ROM; Canada Centre for Mineral and Energy Technology (CANMET): Ottawa, ON, Canada, 1999.

7. Lundgren, T. The dynamics of oxygen transport into soil covered mining waste deposits in Sweden. J. Geochem. Explor. 2001, 74, 163-173. [CrossRef]

8. MEND. Mine Environment Neutral Drainage (MEND) Manual; Volume 4: Prevention and Control; Canada Center for Mineral and Energy Technology: Varennes, QC, Canada, 2001; p. 477.

9. MEND. Design, Construction and Performance Monitoring of Cover Systems for Waste Rock and Tailings; Report No. 2.21.4; Canada Center for Mineral and Energy Technology: Varennes, QC, Canada, 2004.

10. Bussière, B.; Aubertin, M.; Chapuis, R.P. The behavior of inclined covers used as oxygen barriers. Can. Geotech. J. 2003, 40, 512-535. [CrossRef]

11. Bussière, B.; Maqsoud, A.; Aubertin, M.; Martschuk, J.; McMullen, J.; Julien, M. Performance of the Oxygen Limiting Cover at the LTA Site, Malartic, Quebec. CIM Bull. 2006, 1, 1-11.

12. Molson, J.; Aubertin, M.; Bussière, B.; Benzaazoua, M. Geochemical transport modelling of drainage from experimental mine tailings cells covered by capillary barriers. Appl. Geochem. 2008, 23, 1-24. [CrossRef]

13. Maqsoud, A.; Bussière, B.; Aubertin, M.; Chouteau, M.; Mbonimpa, M. Field investigation of a suction break designed to control slope-induced desaturation in an oxygen barrier. Can. Geotech. J. 2011, 48, 53-71. [CrossRef]

14. Blowes, D.; Ptacek, C.; Jambor, J.; Weisener, C.; Paktunc, D.; Gould, W.; Johnson, D. The Geochemistry of Acid Mine Drainage. In Treatise on Geochemistry; Elsevier: Oxford, UK, 2014; pp. 131-190.

15. Smirnova, E.; Bussière, B.; Tremblay, F.; Bergeron, Y. Vegetation Succession and Impacts of Biointrusion on Covers Used to Limit Acid Mine Drainage. J. Environ. Qual. 2011, 40, 133-143. [CrossRef] [PubMed]

16. Canadell, J.G.; Jackson, R.B.; Ehleringer, J.B.; Mooney, H.A.; Sala, O.E.; Schulze, E.-D. Maximum rooting depth of vegetation types at the global scale. Oecologia 1996, 108, 583-595. [CrossRef] [PubMed]

17. Yan, R.; Zhang, G. Soil-water characteristics of compacted sandy and cemented soils with and without vegetation. Can. Geotech. J. 2015, 52, 1331-1344. [CrossRef]

18. Scanlon, B.R. Field study of spatial variability in unsaturated flow beneath and adjacent to playas. Water Resour. Res. 1999, 33, 33-2239. [CrossRef]

19. Leung, A.K.; Garg, A.; Ng, C.W.W. Effects of plant roots on soil-water retention and induced suction in vegetated soil. Eng. Geol. 2015, 193, 183-197. [CrossRef]

20. Li, Y.; Ghodrati, M. Preferential Transport of Nitrate through Soil Columns Containing Root Channels. Soil Sci. Soc. Am. J. 1994, 58, 653-659. [CrossRef]

21. Hu, X.; Li, X.-Y.; Li, Z.-C.; Gao, Z.; Wu, X.-C.; Wang, P.; Lyu, Y.-L.; Liu, L.-Y. Linking 3-D soil macropores and root architecture to near saturated hydraulic conductivity of typical meadow soil types in the Qinghai Lake Watershed, northeastern Qinghai-Tibet Plateau. Catena 2020, 185, 104287. [CrossRef]

22. Guittonny-Larchevêque, M.; Beaulieu, A.; Proteau, A.; Bussière, B.; Maqsoud, A. Vegetation Management on Tailings Impoundments Reclaimed with Covers with Capillary Barrier Effects. In Proceedings of the 5e Symposium on Sediment Management, Montréal, QC, Canada, 10-13 July 2016.

23. Gao, Y.; Xie, Y.; Jiang, H.; Wu, B.; Niu, J. Soil water status and root distribution across the rooting zone in maize with plastic film mulching. Field Crop. Res. 2014, 156, 40-47. [CrossRef]

24. Zhou, Z.; Shangguan, Z. Vertical distribution of fine roots in relation to soil factors in Pinus tabulaeformis Carr. forest of the Loess Plateau of China. Plant Soil 2006, 291, 119-129. [CrossRef]

25. Proteau, A.; Guittonny, M.; Bussière, B.; Maqsoud, A. Oxygen migration through a cover with capillary barrier effects colonized by roots. Can. Geotech. J. 2020. [CrossRef]

26. Guittonny, M.; Bussière, B.; Maqsoud, A.; Proteau, A.; Khouya, T.B.; Botula, Y.-D. Colonisation racinaire dans les recouvrements miniers et impact sur leur fonctionnement. In Proceedings of the Symposium 2018 on Mines and the Environment, Rouyn-Noranda, QC, Canada, 17-20 June 2018.

27. Naeth, M.A.; Chanasyk, D.; Burgers, T. Vegetation and soil water interactions on a tailings sand storage facility in the athabasca oil sands region of Alberta Canada. Phys. Chem. Earth Parts A/B/C 2011, 36, 19-30. [CrossRef]

28. Stoltz, E.; Greger, M. Root penetration through sealing layers at mine deposit sites. Waste Manag. Res. 2006, 24, 552-559. [CrossRef] [PubMed] 
29. Waugh, W.J. Uranium Mill Tailings covers: Evaluating long-term performance. In Proceedings of the International Containment \& Remediation Technology Conference, Orlando, FL, USA, 10-13 June 2001; pp. 10-13.

30. Neuschütz, C.; Stoltz, E.; Greger, M. Root Penetration of Sealing Layers Made of Fly Ash and Sewage Sludge. J. Environ. Qual. 2006, 35, 1260-1268. [CrossRef] [PubMed]

31. O'Kane Consultants Inc. Modelling the Critical Interactions Between Cover Systems and Vegetation; MEND Report 2.21.6; Canada Center for Mineral and Energy Technology: Varennes, QC, Canada, 2014; 52p.

32. Guittonny-Larchevêque, M.; Lortie, S. Above- and Belowground Development of a Fast-Growing Willow Planted in Acid-Generating Mine Technosol. J. Environ. Qual. 2017, 46, 1462-1471. [CrossRef] [PubMed]

33. Garrigues, E.; Doussan, C.; Pierret, A. Water Uptake by Plant Roots: I-Formation and Propagation of a Water Extraction Front in Mature Root Systems as Evidenced by 2D Light Transmission Imaging. Plant Soil 2006, 283, 83-98. [CrossRef]

34. Lambers, H.; Chapin, F.S.; Pons, T.L.; Chapin, F.S. Plant Physiological Ecology; Springer: New York, NY, USA, 2008.

35. Moreno, G.; Obrador, J.; Cubera, E.; Dupraz, C. Fine Root Distribution in Dehesas of Central-Western Spain. Plant Soil 2005, 277, 153-162. [CrossRef]

36. Granier, A.; Barataud, F.; Moyne, C. Soil water dynamics in an oak stand. Plant Soil 1995, 172, $17-27$. [CrossRef]

37. Jackson, R.B.; Canadell, J.G.; Ehleringer, J.R.; Mooney, H.A.; Sala, O.E.; Schulze, E.D. A global analysis of root distributions for terrestrial biomes. Oecologia 1996, 108, 389-411. [CrossRef]

38. Strong, W.L.; La Roi, G.H. Root-system morphology of common boreal forest trees in Alberta, Canada. Can. J. For. Res. 1983, 13, 1164-1173. [CrossRef]

39. Fan, Y.; Miguez-Macho, G.; Jobbágy, E.G.; Jackson, R.B.; Otero-Casal, C. Hydrologic regulation of plant rooting depth. Proc. Natl. Acad. Sci. USA 2017, 114, 10572-10577. [CrossRef]

40. Souch, C.; Martin, P.; Stephens, W.; Spoor, G. Effects of soil compaction and mechanical damage at harvest on growth and biomass production of short rotation coppice willow. Plant Soil 2004, 263, 173-182. [CrossRef]

41. Jackson, M.B.; Attwood, P.A. Roots of willow (Salix viminalis L.) show marked tolerance to oxygen shortage in flooded soils and in solution culture. Plant Soil 1996, 187, 37-45. [CrossRef]

42. Vepraskas, M.J.; Hoyt, G.D. Comparison of the Trench-Profile and Core Methods for Evaluating Root Distributions in Tillage Studies. Agron. J. 1907, 80, 166-172. [CrossRef]

43. Gwenzi, W.; Veneklaas, E.J.; Holmes, K.W.; Bleby, T.M.; Phillips, I.R.; Hinz, C. Spatial analysis of fine root distribution on a recently constructed ecosystem in a water-limited environment. Plant Soil 2011, 344, 255-272. [CrossRef]

44. Di Iorio, A.; Montagnoli, A.; Terzaghi, M.; Scippa, G.S.; Chiatante, D. Effect of tree density on root distribution in Fagus sylvatica stands: A semi-automatic digitising device approach to trench wall method. Trees 2013, 27, 1503-1513. [CrossRef]

45. Bond-Lamberty, B.; Wang, C.; Gower, S.T. Aboveground and belowground biomass and sapwood area allometric equations for six boreal tree species of northern Manitoba. Can. J. For. Res. 2002, 32, 1441-1450. [CrossRef]

46. Gross, M.F.; Hardisky, M.A.; Wolf, P.L.; Klemas, V. Relationship between Aboveground and Belowground Biomass of Spartina alterniflora (Smooth Cordgrass). Estuaries 1991, 14, 180-191. [CrossRef]

47. Schenk, H.J.; Jackson, R.B. Rooting depths, lateral root spreads and below-ground/above-ground allometries of plants in water-limited ecosystems. J. Ecol. 2002, 90, 480-494. [CrossRef]

48. Körner, C.; Renhardt, U. Dry matter partitioning and root length/leaf area ratios in herbaceous perennial plants with diverse altitudinal distribution. Oecologia 1987, 74, 411-418. [CrossRef]

49. Young, I.W.R.; Naguit, C.; Halwas, S.J.; Renault, S.; Markham, J. Natural Revegetation of a Boreal Gold Mine Tailings Pond. Restor. Ecol. 2012, 21, 498-505. [CrossRef]

50. Kovář, P.; Štefánek, M.; Mrázek, J. Responses of Vegetation Stages with Woody Dominants to Stress and Disturbance During Succession on Abandoned Tailings in Cultural Landscape. J. Landsc. Ecol. 2011, 4, 35-48. [CrossRef]

51. Bradshaw, A. The use of natural processes in reclamation-Advantages and difficulties. Landsc. Urban Plan. 2000, 51, 89-100. [CrossRef] 
52. Cuevas, J.G.; Silva, S.I.; León-Lobos, P.; Ginocchio, R. Nurse effect and herbivory exclusion facilitate plant colonization in abandoned mine tailings storage facilities in north-central Chile. Rev. Chil. Hist. Nat. 2013, 86, 63-74. [CrossRef]

53. Kimmerer, R.W. Vegetation Development on a Dated Series of Abandoned Lead and Zinc Mines in Southwestern Wisconsin. Am. Midl. Nat. 1984, 111, 332-341. [CrossRef]

54. Benson, C.H.; Thorstad, P.A.; Jo, H.Y.; Rock, S.A. Hydraulic Performance of Geosynthetic Clay Liners in a Landfill Final Cover. J. Geotech. Geoenviron. Eng. 2007, 133, 814-827. [CrossRef]

55. Bouazza, A. Geosynthetic clay liners. Geotext. Geomembr. 2002, 20, 3-17. [CrossRef]

56. Párraga-Aguado, I.; Querejeta, J.I.; González-Alcaraz, M.N.; Jiménez-Cárceles, F.J.; Conesa, H.M. Usefulness of pioneer vegetation for the phytomanagement of metal(loid)s enriched tailings: Grasses vs. shrubs vs. trees. J. Environ. Manag. 2014, 133, 51-58. [CrossRef]

57. Dagenais, A.-M.; Aubertin, M.; Bussière, B.; Bernier, L.; Cyr, J. Monitoring at the Lorraine Mine Site: A Follow-Up on the Remediation Plan. In Proceedings of the National Association of Abandoned Mine Land Programs Annual Conference, Athens, OH, USA, 19-22 August 2001; pp. 1-19.

58. Genty, T.; Bussière, B.; Paradie, M.; Neculita, C.M. Passive Biochemical Treatment of Ferriferous Mine Drainage: Lorraine Mine Site, Northern Québec, Canada. In Proceedings of the International Mine Water Association (IMWA) Conference, Leipzig, Germany, 11-15 July 2016; pp. 790-795.

59. Nastev, M.; Aubertin, M. Hydrogeological Modelling for the Reclamation Work at the Lorraine Mine Site, Québec. In Proceedings of the 1st Joint IAH-CNC and CGS Groundwater Specialty Conference, Montreal, QC, Canada, 15-18 October 2020.

60. Potvin, R. Évaluation à Différentes Échelles de la Performance de Systèmes de Traitement Passif Pour des Effluents Fortement Contaminés par le Drainage Minier Acide. Ph.D. Thesis, Université du Québec en Abitibi-Témiscamingue, Noranda, QC, Canada, 2009.

61. MFFP, Gouvernement du Québec. Zones de Végétation et Domaines Bioclimatiques du Québec. Available online: https://mffp.gouv.qc.ca/forets/inventaire/inventaire-zones-carte.jsp (accessed on 14 August 2017).

62. Government of Canada. Mean Climatic Data from 1981 to 2010 for Ville-Marie Station. Available online: http://climat.meteo.gc.ca/climate_normals/results_1981_2010_f.html?stnID=6002\&lang=f\&province= QC\&provSubmit $=$ go\&page $=151 \& \mathrm{dCode}=0$ (accessed on 14 August 2017).

63. Bussière, B.; Potvin, R.; Dagenais, A.-M.; Aubertin, M.; Maqsoud, A.; Cyr, J. Restauration du site minier Lorraine, Latulipe, Québec: Résultats de 10 ans de suivi. Déchets Sci. Tech. 2009, 54, 49-64. [CrossRef]

64. Jonasson, S. The point intercept method for non-destructive estimation of biomass. Phytocoenologia 1983, 11, 385-388. [CrossRef]

65. Bonan, G.B.; Sirois, L. Air temperature, tree growth, and the northern and southern range limits toPicea mariana. J. Veg. Sci. 1992, 3, 495-506. [CrossRef]

66. Black, R.A.; Bliss, L.C. Reproductive Ecology of Picea Mariana (Mill.) BSP., at Tree Line Near Inuvik, Northwest Territories, Canada. Ecol. Monogr. 1980, 50, 331-354. [CrossRef]

67. Jones, C.C.; Del Moral, R. Patterns of Primary Succession on the Foreland of Coleman Glacier, Washington, USA. Plant Ecol. 2005, 180, 105-116. [CrossRef]

68. Chapin, F.S.; Walker, L.R.; Fastie, C.L.; Sharman, L.C. Mechanisms of Primary Succession Following Deglaciation at Glacier Bay, Alaska. Ecol. Monogr. 1994, 64, 149-175. [CrossRef]

69. Huang, L.-N.; Tang, F.-Z.; Song, Y.-S.; Wan, C.-Y.; Wang, S.-L.; Liu, W.-Q.; Shu, W.-S. Biodiversity, abundance, and activity of nitrogen-fixing bacteria during primary succession on a copper mine tailings. FEMS Microbiol. Ecol. 2011, 78, 439-450. [CrossRef] [PubMed]

70. Egli, M.; Wernli, M.; Kneisel, C.; Haeberli, W. Melting Glaciers and Soil Development in the Proglacial Area Morteratsch (Swiss Alps): I. Soil Type Chronosequence. Arct. Antarct. Alp. Res. 2006, 38, 499-509. [CrossRef]

71. Frenot, Y.; Van Vliet-Lanoë, B.; Gloaguen, J.-C. Particle Translocation and Initial Soil Development on a Glacier Foreland, Kerguelen Islands, Subantarctic. Arct. Alp. Res. 1995, 27, 107-115. [CrossRef]

72. Boy, J.; Godoy, R.; Shibistova, O.; Boy, D.; McCulloch, R.; De La Fuente, A.A.; Morales, M.A.; Mikutta, R.; Guggenberger, G. Successional patterns along soil development gradients formed by glacier retreat in the Maritime Antarctic, King George Island. Rev. Chil. Hist. Nat. 2016, 89, 76. [CrossRef]

73. Song, M.; Yu, L.; Jiang, Y.; Lei, Y.; Korpelainen, H.; Niinemets, Ü.; Li, C. Nitrogen-controlled intra-and interspecific competition between Populus purdomii and Salix rehderiana drive primary succession in the Gongga Mountain glacier retreat area. Tree Physiol. 2017, 37, 799-814. [CrossRef] 
74. Porter, R.; LaCourse, T.; Hawkins, B.; Yanchuk, A. Adaptive variation in growth, phenology, cold tolerance and nitrogen fixation of red alder (Alnus rubra Bong.). For. Ecol. Manag. 2013, 291, 357-366. [CrossRef]

75. Bradshaw, A.D. The Reconstruction of Ecosystems: Presidential Address to the British Ecological Society, December 1982. J. Appl. Ecol. 1983, 20, 1. [CrossRef]

76. Kendle, A.D.; Bradshaw, A.D. The role of soil nitrogen in the growth of trees on derelict land. Arboric. J. 1992, 16, 103-122. [CrossRef]

77. Walters, M.B.; Reich, P.B. Seed size, nitrogen supply, and growth rate affect tree seedling survival in deep shade. Ecology 2000, 81, 1887-1901. [CrossRef]

78. Payandeh, B.; Haavisto, V.F. Prediction Equations for Black Spruce Seed Production and Dispersal in Northern Ontario. For. Chron. 1982, 58, 96-99. [CrossRef]

79. McVean, D.N. Ecology of Alnus Glutinosa (L.) Gaertn.: II. Seed Distribution and Germination. J. Ecol. 1955, 43, 61-71. [CrossRef]

80. Shearer, R.C. Proceedings_-Conifer Tree Seed in the Inland Mountain West Symposium, Missoula, Montana, 5-6 August 1985; US Department of Agriculture, Forest Service, Intermountain Research Station: Missoula, MT, USA, 1986; Volume 203.

81. Lezberg, A.L.; Antos, J.A.; Halpern, C.B. Belowground traits of herbaceous species in young coniferous forests of the Olympic Peninsula, Washington. Can. J. Bot. 1999, 77, 936-943.

82. Guittonny, M. Root Colonization in Mine Covers and Impact on Their Functioning. In Proceedings of the 43rd CLRA/ACRSD National Conference and AGM/ARC 2018 Event, Miramichi, NB, Canada, 15-18 October 2018.

83. Mishra, H.S.; Rathore, T.R.; Pant, R.C. Root growth, water potential, and yield of irrigated rice. Irrig. Sci. 1997, 17, 69-75. [CrossRef]

84. Mishra, H.S.; Rathore, T.R.; Tomar, V.S. Root growth, water potential and yield of irrigated wheat. Irrig. Sci. 1999, 18, 117-123. [CrossRef]

85. Pauliukonis, N.; Schneider, R. Temporal patterns in evapotranspiration from lysimeters with three common wetland plant species in the eastern United States. Aquat. Bot. 2001, 71, 35-46. [CrossRef]

86. Amato, M.; Basso, B.; Celano, G.; Bitella, G.; Morelli, G.; Rossi, R. In situ detection of tree root distribution and biomass by multi-electrode resistivity imaging. Tree Physiol. 2008, 28, 1441-1448. [CrossRef]

87. Naghdi, R.; Maleki, S.; Abdi, E.; Mousavi, R.; Nikooy, M. Assessing the effect of Alnus roots on hillslope stability in order to use in soil bioengineering. J. For. Sci. 2013, 59, 417-423. [CrossRef]

88. Rytter, L. Distribution of roots and root nodules and biomass allocation in young intensively managed grey alder stands on a peat bog. Plant Soil 1989, 119, 71-79. [CrossRef] 